\title{
A Hospital-Based Clinical Study of Herpes Zoster- A report of 113 cases
}

\author{
Dr. Pankaj Adhicari ${ }^{1}$,Dr. Kumud Agarwal ${ }^{2}$ \\ ${ }^{1}$ Associate Professor, Department of Dermatology, Gauhati Medical College and Hospital, Guwahati, India, \\ ${ }^{2}$ Consultant Dermatologist, Brahmaputra Hospital and Diagnostics Limited, Dibrugarh,,India,
}

\begin{abstract}
Herpes zoster is caused by "varicella zoster virus"- a neurodermotropic virus which is distributed worldwide. It is characterized by unilateral radicular pain and grouped vesicular eruption that is generally limited to the dermatome innervated by a single spinal or cranial sensory ganglion. A prospective observational study was conducted in the Department of Dermatology of the Assam Medical College \& Hospital, Dibrugarh, Assam over a period of 1 year from July 2013 to June 2014. During this period 113 clinically diagnosed cases of Herpes Zoster attending Dermatology OPD were included in the Study. A detailed history was taken and clinical evaluation was done. Relevant investigations were carried out whenever necessary and the findings were recorded in a proforma for analysis and interpretation of data. The occurrence of herpes zoster amongst $O P D$ cases was recorded to be $0.51 \%$. The herpes zoster cases included 71 males and 42 females and the male: female ratio was 1.69:1. Maximum number of cases was seen in patients from 31-40 years of age $(28 ; 24.78 \%)$. A definite positive past history of chicken pox was present in (90; 79.65\%). Thoracic dermatome was the most common dermatome to be involved $(51 ; 45.13 \%)$.
\end{abstract}

Keywords: Dermatome, herpes zoster, radicular, varicella zoster virus

\section{Introduction}

Herpes zoster is caused by "varicella zoster virus"- a neurodermotropic virus which is distributed worldwide. It is characterized by unilateral radicular pain and grouped vesicular eruption that is generally limited to the dermatome innervated by a single spinal or cranial sensory ganglion. It occurs as a result of reactivation of the latent virus from within the sensory ganglion [1-3] following an earlier attack of varicella.

The reactivation of the virus may be due to immune suppression (inherited, acquired or iatrogenic) or spontaneous. In HIV patients it may present in diverse manner such as multidermatomal involvement, crusted, nodular, vesiculopustular, ulcerative or ecthymatous [5-7] lesions that may be widely disseminated [5,8-10] or localized [10].

Post herpetic neuralgia (PHN) is a most important and troublesome complication, which is very tiring to the patient as well as to the physician and till date there is no single effective drug to cure this distressing problem [11]. Acyclovir has been the oral antiviral agent approved for the treatment of patients with acute herpes zoster, its effect on post herpetic neuralgia remains controversial $[12,13]$.

\section{Objectives}

To study the clinical profile of Herpes zoster patients attending a tertiary care center.

\section{Materials And Methods}

This was a prospective observational study conducted in the Department of Dermatology of the Assam Medical College \& Hospital, Dibrugarh, Assam. The study was conducted over a period of 1 year from July 2013 to June 2014. During this period 113 clinically diagnosed cases of Herpes Zoster attending Dermatology OPD were included in the Study. Ethical clearance was taken before performing the study and informed consent from patients was also taken.

Patient particulars like age, sex, address and occupation were noted. A detailed history regarding prodromal and presenting symptoms, day of occurrence and types of skin lesions, the nature, severity and character of pain were noted. Past history of chicken pox if any was noted. History suggestive of any provocative factors was also sought. A thorough general physical examination and local cutaneous was done and findings were recorded. Whenever required,opinion from other specialists wassought. Complete haemogram, blood sugar, routine urine examination and ELISA for HIV $1 \& 2$ were done. All patients were reviewed weekly for 1 month and then monthly for 3 months. 


\section{Results}

One Hundred and thirteen (113) cases of herpes zoster were recorded during July 2013 to June 2014. A total of 22228 new cases attended Dermatology OPD during the study period, giving the frequency of occurrence of herpes zoster amongst OPD cases to be $0.51 \%$. The herpes zoster cases included 71 males and 42 females and the male: female ratio was 1.69:1.

The mean age of presentation was 45.75 years with the range from 12 to 80 years. Maximum number of cases were seen in patients from 31-40 years of age (28; 24.78\%), followed by cases in 41-50 years (25; $22.12 \%)$ ).). Males outnumbered females in all almost all age groups except in 51-60 years. 21 cases (18.58\%) were above 60 years of age. The age and sex distribution of the patients is shown in TABLE 1.

Table 1:Age and sex distribution

\begin{tabular}{|l|l|l|l|l|l|l|}
\hline \multirow{2}{*}{$\begin{array}{c}\text { Age Group } \\
\text { (In Years) }\end{array}$} & Male & Female & \multicolumn{2}{l|}{ Total } \\
\cline { 2 - 7 } & $\mathrm{N}$ & $\%$ & $\mathrm{~N}$ & $\%$ & $\mathrm{~N}$ & $\%$ \\
\hline $0-10$ & 0 & 0.00 & 0 & 0.00 & 0 & 0.00 \\
\hline $11-20$ & 3 & 100.00 & 0 & 0.00 & 3 & 2.65 \\
\hline $21-30$ & 11 & 57.89 & 8 & 42.11 & 19 & 16.81 \\
\hline $31-40$ & 19 & 67.86 & 9 & 32.14 & 28 & 24.78 \\
\hline $41-50$ & 16 & 64.00 & 9 & 36.00 & 25 & 22.12 \\
\hline $51-60$ & 8 & 47.06 & 9 & 52.94 & 17 & 15.04 \\
\hline $61-70$ & 10 & 76.92 & 3 & 23.08 & 13 & 11.50 \\
\hline $71-80$ & 4 & 50.00 & 4 & 50.00 & 8 & 7.08 \\
\hline$>/=81 \&$ Above & 0 & 0.00 & 0 & 0.00 & 0 & 0.00 \\
\hline TOTAL & 71 & 62.83 & 42 & 37.17 & 113 & 100 \\
\hline
\end{tabular}

Most common occupation of these patients was that of house wife $(37 ; 32.64 \%)$ followed by Farmer $(20 ; 17.70 \%)$, Service man $(18 ; 15.93 \%)$, Businessman $(16 ; 14.16 \%)$, Daily Manual Labourer $(8 ; 7.08 \%)$, tudent (7; 6.19\%), Unemployed $(6 ; 5.31 \%)$ and Professional $(1 ; 0.88 \%)$. The duration of illness on presentation was maximum in $0-3$ days in $(58 ; 51.33 \%)$ followed by $4-7$ days $(40: 35.40 \%)$, and $>7$ days $(15 ; 13.27 \%)$. rodromal symptoms were present in $(70 ; 61.95 \%)$ whereas it was absent in $(43 ; 38.05 \%)$. Burning sensation $(25 ; 22.12 \%)$ was the most common prodromal symptom followed by Watering from eyes and Itching in $(9 ; 7.96 \%)$ each, Paraesthesia in $(7 ; 6.19 \%)$, Fever and Tingling in $(6 ; 5.31 \%)$ each, Headache in $(5 ; 4.42 \%)$ and others in $(3$; $2.65 \%)$.

Skin eruptions were the most common presenting symptom $(112 ; 99.12 \%)$ followed by Pain (102; $90.27 \%)$ and localized itching $(8 ; 7.08 \%)$. Most common type of pain was Burning pain $(52 ; 46.02 \%)$ followed by Stabbing pain $(28 ; 24.78 \%)$ and Shooting pain $(13 ; 11.50 \%)$. A definite positive past history of chicken pox was present in $(90 ; 79.65 \%)$ whereas past history of chicken pox was absent in $(23 ; 20.35 \%)$. A surge of cases were seen in March $(13 ; 11.50 \%)$, April $(15 ; 13.27 \%)$, May $(12 ; 10.62 \%)$, and then in August $(17 ; 15.04 \%)$ and September $(15 ; 13.27 \%)$.

Table 2: Dermatomes Involved

\begin{tabular}{|l|l|l|l|l|l|l|}
\hline \multirow{2}{*}{ Dermatome Involved } & \multicolumn{2}{|l|}{ Right } & Left & \multicolumn{2}{l|}{ Total } \\
\cline { 2 - 7 } & $\mathrm{N}$ & $\%$ & $\mathrm{~N}$ & $\%$ & $\mathrm{~N}$ & $\%$ \\
\hline Cranial & 15 & 46.88 & 17 & 53.13 & 32 & 28.32 \\
\hline Cervical & 6 & 54.55 & 5 & 45.45 & 11 & 9.74 \\
\hline Thoracic & 30 & 58.82 & 21 & 41.18 & 51 & 45.13 \\
\hline Lumbar & 8 & 47.06 & 9 & 52.94 & 17 & 15.04 \\
\hline Sacral & 1 & 50.00 & 1 & 50.00 & 2 & 1.77 \\
\hline Total & 60 & 53.10 & 53 & 46.90 & 113 & 100 \\
\hline
\end{tabular}

Thoracic dermatome was the most common dermatome to be involved $(51 ; 45.13 \%)$ followed by cranial $(32 ; 28.32 \%)$ and lumbar $(17 ; 15.04 \%)$. Right side was more commonly involved in Thoracic (30; $58.82 \%)$ vs $(21 ; 41.18 \%)$ and Cervical $(6 ; 54.55 \%)$ vs $(5 ; 45.45 \%)$ dermatome whereas Lumbar $(8 ; 47.06 \%)$ vs $(9 ; 52.94 \%)$ and Cranial dermatome $(15 ; 46.88 \%)$ vs $(17 ; 53.13 \%)$ were commonly involved in the left side. Out of 113 cases of Herpes Zoster, 18 cases of Herpes Zoster Ophthalmicuswere seen $(18 ; 15.93 \%)$. Precipitating factors were present in 22 cases $(19.47 \%)$ whereas it was absent in 91 cases $(80.53 \%)$. Most common precipitating factors seen in the study is diabetes $(11 ; 9.73 \%)$ followed by immunosuppressive drugs $(5 ; 4.42 \%)$ and tuberculosis $(3 ; 2.65 \%)$. Complications were seen in 43 cases $(38.05 \%)$. Most common complication seen was post-herpetic neuralgia $(16 ; 14.15 \%)$ followed by pigmentary changes $(11 ; 9.73 \%)$, scarring $(8 ; 7.08 \%)$, secondary bacterial infection $(4 ; 3.54 \%)$, keloid $(2 ; 1.77 \%)$, and dissemination $(1 ; 0.88)$. Maximum cases of PHN were seen in the age group $61-70$ years $(5 ; 31.25 \%)$ followed by $51-60$ years and $41-50$ years $(3 ; 18.75 \%)$. 


\section{Discussion}

113 cases were diagnosed to have Herpes Zoster giving the Occurrence of $0.51 \%$. Similar incidence of Herpes Zoster has been noted in different studies; 0.34\% (Dubeyet al 2005)[14], $0.65 \%$ (Kayasthaet al 2009)[15], 0.60\%(Uddinet al 2010) [16], 0.46\% (Suhailet al 2011)[17].

The maximum number of cases was seen in patients from 31-40 years of age $(28 ; 24.78 \%)$ (From Table 1).Chaudharyet al (1987)[18] reported maximum cases in 20-30 years age group (28\%) Whereas, Dubeyet al (2005)[14]in 14-29 years age group (37.62\%), Kayasthaet al (2009)[15] in 20-29 years age group (32.76\%), Latheefet al (2011)[19] in 31-40 years age group (24\%). There were $71(62.83 \%)$ males and $42(37.17 \%)$ females in our study and males outnumbered females with a ratio of 1.69:1, which is in accordance with study of Dubeyet al (2005)[14] which showed 1.74: 1. Latheefet al (2011)[19] found a male: female ratio of 1.33: 1 . Uddinet al (2010)[16] found a male to female sex ratio was 1.4: 1.0.Kayasthaet al (2009)[15] found among 174 cases $119(68.39 \%)$ were males and $55(31.61 \%)$ were females, the male: female ratio being 2.16: 1 .

Our study is consistent with most studies cited above however Kayasthaet al(2009)[15] found a little higher ratio of 2.16: 1 while Chaudharyet al (1987) 2.2: 1 and Gohet al [20] in their study found equal incidence in men and women.

In the present study it was seen that a surge of cases were seen in March (13; 11.50\%), April (15; 13.27\%), May (12; 10.62\%), and then in August $(17 ; 15.04 \%)$ and September $(15 ; 13.27 \%)$. Chaudharyet al[55] noted increased incidence in the months of August, September and October. Nigam et al[21] found increased incidence during March, April, August, September and December. Sehgalet al[22] did not find any seasonal variation. Ragozzinoet al[23] also contend that there is no clear evidence of seasonal trends in incidence of zoster. Kayasthaet al (2009)[15]the disease was more prevalent during the months of Baishakh to Ashad (midApril to mid-July).

Table3: Segmental distribution

\begin{tabular}{|l|l|l|l|l|}
\hline \multirow{2}{*}{ Studies } & \multicolumn{4}{|c|}{ Segments (\%) } \\
\cline { 2 - 5 } & Cranial & Cervical & Thoracic & Lumbar \\
\hline Hope - Simpson $E t A l(1965)[24]$ & 13.0 & 14.0 & 50.0 & 17.0 \\
\hline Ragozzino $E t A l(1982)[23]$ & 13.4 & 11.2 & 56.4 & 17.0 \\
\hline Burgoon $E t A l(1957)[25]$ & 20.0 & 11.0 & 55.0 & 15.0 \\
\hline Hellgren $E t A l(1966)[26]$ & 20.0 & 18.0 & 44.0 & 18.0 \\
\hline Sehgal $E t A l(1976)[22]$ & 8.8 & 20.0 & 52.5 & 18.8 \\
\hline Nigam $E t A l(1972)[21]$ & 7.4 & 13.3 & 73.0 & 5.7 \\
\hline Mathur $E t A l(1967)[27]$ & 8.0 & 10.0 & 75.0 & 7.0 \\
\hline Chaudhary $E t A l(1987)[18]$ & 11.3 & 19.5 & 55.2 & 13.0 \\
\hline Dubey $E t A l(2005)[14]$ & 14.95 & 15.89 & 59.81 & 12.15 \\
\hline Kayastha $E t A l(2009)[15]$ & 12.02 & 16.66 & 56.33 & 8.62 \\
\hline Latheef $E t A l(2011)[19]$ & 28.2 & 12.1 & 42.4 & 7.8 \\
\hline Present Study $(2013-14)$ & 28.32 & 9.74 & 45.13 & 15.04 \\
\hline
\end{tabular}

From Table 3, Thoracic segment was most commonly involved followed by Cranial, Cervical Lumbosacral segments, which is in agreement with the other studies [25][26].

In the present Study prodromal symptoms were present in $(70 ; 61.95 \%)$ whereas it was absent in (43; $38.05 \%$ ) which is in consistent with Dubey et al (2005)[14] (68.22\%). Whereas earlier studies like Chaudhary et al (1987)[18] and Mittal et al (1995)[30] reported prodormal symptoms to be present in 20\% and 36\% of cases. Past history of chicken pox was present in (90; 79.65\%). Latheef et al (2011)[19] found a definite history of chicken pox in 63.4\% of cases. Boley et al (1990)[31] reported 50\% of the patients will develop herpes zoster who had a past history of chicken pox. Simpson (1954)[24] also recorded a high incidence of herpes zoster among patients who had the past history of chicken pox.

The most common precipitating factors seen in the study is Diabetes $(11 ; 9.73 \%)$ followed by immunosuppressive drugs $(5 ; 4.42 \%)$, Tuberculosis $(3 ; 2.65 \%)$ and HIV in $1(0.88 \%)$ case. Dubey et al (2005)[14] found 9 patients had corticosteroid therapy, 5 patients with chemotherapy and radiotherapy, Diabetes in 3 patients and tuberculosis in 3 patients. Uddin et al (2010)[16] found three cases had chemotherapy and two on corticosteroid therapy with diabetes mellitus in nine cases, pulmonary tuberculosis 1 case, 1 case thalassemia and 1 case with chronic renal failure. 


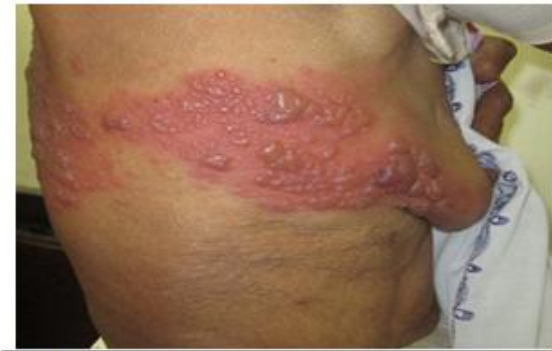

Fig 1: Herpes Zoster involving T4 dermatome.

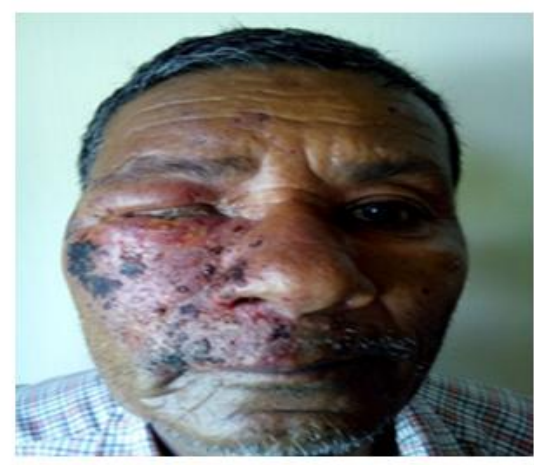

Fig 3: Herpes Zoster involving V2 division of Trigeminal nerve.
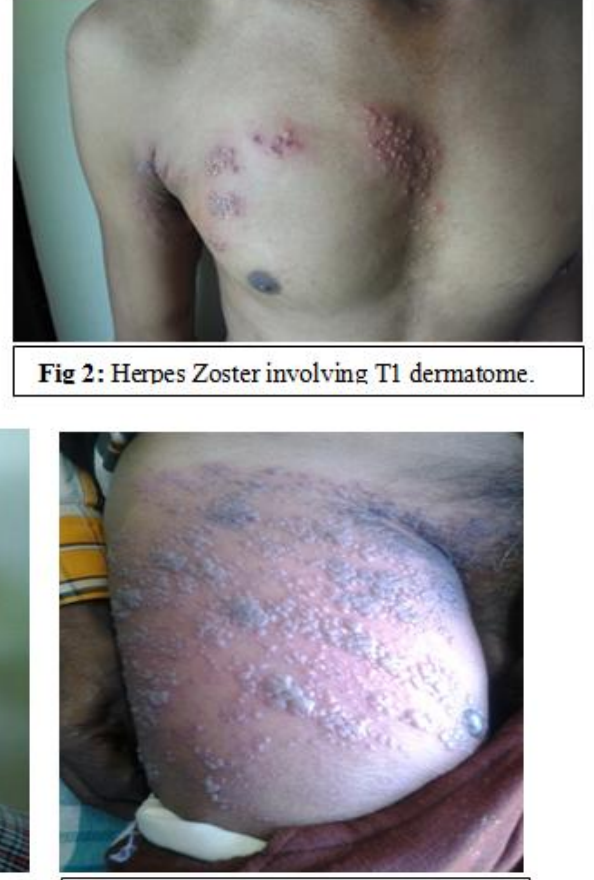

Fig 4: Herpes Zoster involving L1, L2 dermatome.

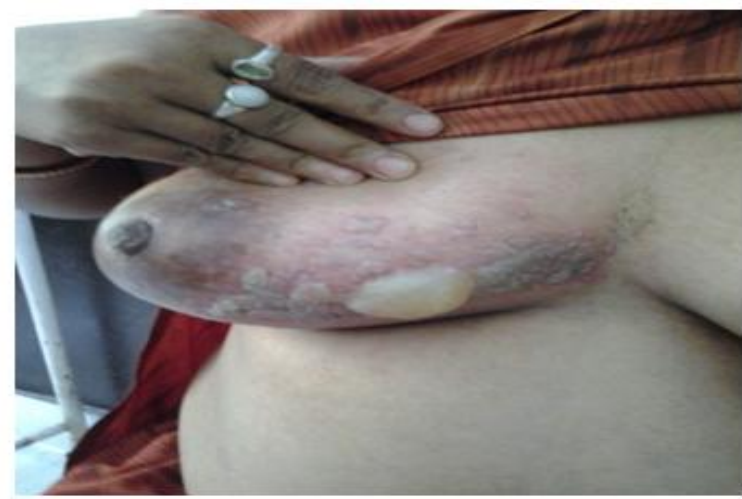

Fig 5: Herpes Zoster involving T5 dermatome with bullous lesion.

Iatrogenic Immunosuppresion, HIV, Diabetes and Tuberculosis were the common precipitating factors and associated diseases seen. Complications were seen in 42 cases(37.16\%), The most common complication being PHN $(16 ; 14.15 \%)$ and others being secondary bacterial infection, pigmentary changes, keloid formation, post-herpetic itching and Facial Palsy with unilateral deafness and corneal ulcer in 1 case each. The incidence of PHN was found to be equal in male and females. In a study done by Dubeyet al (2005)[14] complications occurred in 43 patients (40.19\%) and 71 patients (34.6\%) in a study done by Latheefet al (2011)[19].

Table 4: Incidence of PHN

\begin{tabular}{|l|c|}
\hline \multicolumn{1}{|c|}{ Author (Year) } & $\begin{array}{c}\text { Incidencephn } \\
(\%)\end{array}$ \\
\hline Rogozzinoet Al (1982)[23] & 9.0 \\
\hline Burgoon (1957)[25] & 9.7 \\
\hline Fitzpatrick Et A[32] & 15.0 \\
\hline Straus Et Al (1988)[33] & 14.0 \\
\hline Church Et Al (1972)[34] & 10.0 \\
\hline Sehgalet Al (1976)[22] & 11.0 \\
\hline Nigam Et Al (1991)[21] & 11.3 \\
\hline Chaudharyet Al (1987)[18] & 14.3 \\
\hline Dubeyet Al (2005)[14] & 14.95 \\
\hline
\end{tabular}




\begin{tabular}{|l|c|}
\hline Uddinet $\mathrm{Al}(2010)[16]$ & 9.75 \\
\hline Latheefet $\mathrm{Al}(2011)[19]$ & 10.24 \\
\hline Present Study (2013-14) & 14.16 \\
\hline
\end{tabular}

From the above Table 4, it is seen that the finding of the present study is consistent with the most of the studies.[32,33,18,14] whereas, some studies shows a little lesser incidence of PHN which may be due to more proportion of younger population in those studies $[23,25,34,16]$. The incidence of PHN in both males and females are equal. Maximum incidence of PHN is seen in 61-70 years age group. In the present study a single case $(0.88 \%)$ of disseminated zoster was seen. Nigintonet al (1992)[35] reported 2-5\% cases of disseminated herpes zoster. Juel-Jensen and Mac-Collum (1972)[36] reported 16.5\% cases of disseminated herpes zoster in a series of 91 patients. They observed that all the cases of disseminated herpes zoster are above 60 years of age. John et al (1964) [37],Bumbet al (1989)[38] observed 40\% of the cases of disseminated herpes zoster with Hodgkin's disease and internal malignancy. Marsilaset al(1964)[39] reported 17 cases of disseminated herpes zoster and the 4 cases who died all had underlying malignant disease. One patient presented with corneal ulcer and scarring, resulting in corneal opacity with loss of vision in one eye.

\section{Conclusion}

The disease preferentially involves older age group while being a rarity in children. Various precipitating factors and diseases may be associated with Herpes Zoster. So, always a suspicion of underlying immunosuppression or diseases like HIV, Tuberculosis or Malignancy should be kept in mind whenever a diagnosis of Herpes Zoster is sought. Some forms of Herpes Zoster like Herpes Zoster Ophthalmicus, RamsayHunt Syndrome should be promptly diagnosed and treated because they always pose a risk for permanent damage of vital structures like the eye, ear or the facial nerve.

\section{References}

[1]. Pavithran K. An clinical study of five hundred cases of herpes zoster. Antiseptic 1986;83:682-5.

[2]. Peeneys N. Diseases caused by viruses. In: Elder D, editor. Lever's Histopathology of the skin. 8th ed. Philadelphia:Lippincott Raven; 1997. p. 569-89.

[3]. Whitley RJ. Varicella zoster virus. In: Mandell GL, BennetJE,Dolin R, editors. Principles and practice of infectious diseases.4th ed. New York: Churchill Livingstone; 1995. p. 1345-51.

[4]. Donahue JG, Choo PW, Manson JE, Platt R. The incidence of herpes zoster. Arch Intern Med 1995; $155: 1605-1609$.

[5]. Schacker T, Corey L. Herpes virus infections in HIV infected person. In: Devita VT, Samuel Hailman, Lisenberg SA, editors.Textbook of AIDS. 4th ed. Philadelphia: Lippincott - Raven;1997. p. 267-80.

[6]. Smith KJ, Skelton HG, Yeager J. Cutaneous findings in HIV - 1 positive patients: A 42 - months' prospective study. J Am AcadDermatol 1994;3:746-54.

[7]. Watson PN, Evens RJ. Post herpetic neuralgia: A review. Arch Neural 1986;43:836-40.

[8]. Happenjans WB, Bibler MR, Orme RL. Prolonged cutaneous herpes zoster in acquired immunodeficiency syndrome.ArchDermatol 1988;126:1048.

[9]. Reusser P. Herpesvirus resistance to antiviral drugs: A review of the mechanisms, clinical importance and therapeutic options. J Hosp Infect 1996;33:235-48.

[10]. Bernhard P, Obel N. Chronic ulcerating acyclovir resistant varicella zoster lesions in an AIDS patient. Scand J Infect Dis 1996;27:623-5

[11]. Thiers BH, Sahn EE. Varicella zoster virus infections. In: Samuel L, Moschella, Harry J, Hurley, editors. Dermatology. 3rd ed. Philadelphia: W.B. Saunders Company; 1992. p. 797-806.

[12]. Strommen GL, Pucino F, Tight RR, Beck CL. Human infection with herpes Zoster: Etiology, pathophysiology, diagnosis, clinical course and treatment.Pharmacotherapy. 1988; 8: 52-68.

[13]. Huff JC, Bean B, Balfour HH, Jr, Laskin OL, Connor JD, Corey L. Therapy of herpes zoster with oral acyclovir. Am J Med. 1988:85:84-89.

[14]. Dubey AK, Jaisankar TJ, Thappa DM. Clinical and morphological characteristics of herpes zoster in South India. Indian J Dermatol 2005; 50: 203-7.

[15]. Kayastha BMM, Shrestha P, Lama L. Changing Profile of Herpes Zoster in Nepal. Nepal J of Dermatol 2009; 8 (1):1-4

[16]. Uddin M R, Bhuyan MMH, Akhter F. Study on Morphological and Clinical Aspects of Herpes Zoster in a Tertiary Medical College Hospital. Medicine Today 2010;22 (2):80-82.

[17]. Suhail M, Ejaz A, Abbas M, Naz S, Suhail T. Herpes zoster: seasonal variations and morphological patterns in Pakistan. J Pak Asso of Dermatol 2011; 21; 22-26.

[18]. Chaudhary SD, Dashore A, Pahwa US. A clinico-epidemiologic profile of herpeszoster in North India. Indian J DermatolVenereolLeprol 1987;53:213-16.

[19]. Abdul Latheef EN, Pavithran K. Herpes Zoster. A clinical study in 205 patients. Indian J Dermatol 2011;56:529-32

[20]. Goh CE, Khoo L. A retrospective study of the clinical presentation and outcomeof herpes zoster in a tertiary dermatology outpatient referral clinic.Int J Dermatol, 1997;36:667-672.

[21]. Nigam P, Tandon VK, Kumar R, Sahai I, Agrawal LP. Herpes zoster - A clinicalstudy. Indian J DermatolVenereol 1972;38 (4):15255 .

[22]. Sehgal VN, Rege VL, Kharangate VN and Reys M. The natural history of Herpes zoster. Indian J DermatolVenereolLeprol 1976; 42 (2): 86-89.

[23]. Ragozzino MW, Mellon IJ, Kurland LT, Chu CP, Perry HO. Population based study of herpes zoster and its sequelae. Medicine 1982;6:310-316

[24]. Edgar Hope R, Simpson. The nature of Herpes zoster.A long-term study and a new hypothesis.Proc Roy Soc Med 1965; 58: 9-20.

[25]. Burgoon CF, Jr. Burgoon JS, Baldridge GD. The natural history of Herpes zoster JAMA 1957; 164: $265-69$. 
[26]. Hellgren L, Hersle K. A statistical and clinical study of Herpes Zoster Geront.Clin 1966; 8: 70-76.

[27]. Mathur MP, Mathur AK, Saxena HC, Bhatia RK. Herpes zoster- A clinical study. Indian J Med Assoc 1967;49 (5):237-40.

[28]. Hellgren L, Hersle K. A statistical and clinical study of Herpes Zoster Geront.Clin 1966; 8: 70-76.

[29]. Burgoon CF, Jr. Burgoon JS, Baldridge GD. The natural history of Herpes zoster JAMA 1957; 164: $265-69$.

[30]. Mittal RR, Gill SS KourKiranjit and Chopra AK 1994. Unilateral Multisegmental herpes zoster in a normal child. Indian J Dermol, Venereal, Leperol 60:362-63.

[31]. Boley T, Curtis J. Herpes Zoster etiology, clinical course and suggested management. J Am Acad.Nursepracts. 1990. April-June; 2 (2),64-68.

[32]. OxmanMN,Schmader KE,. Varicella and Herpes Zoster. In: Goldsmith LA, Katz SI, Gilchrest BA, Paller AS, Leffell DJ, Wolff K Editors. Fitzpatrik'sDermatology in General Medicine. 8th Edn., New York : McGraw Hill MedPublicating Division; 2012;pp23832401

[33]. Straus SE, Ostrove JM, Inchauspe G, Felser JM, Freifeld A, Croen KD, Sawyer MH. Varicella-zoster virus infections. Ann Int Med 1988;108:221-237.

[34]. Ronald Church. Herpes zoster.The practitioner 1972; 208: 607-13.

[35]. Sterling JC. Virus infection.In : Burns T, Breathnach S, Cox N, Griffiths C.editors. Rook's text book of Dermatology, 8th Edition. Blackwell Science Ltd.,2010;33.22-33.28.

[36]. Juel-Jensen BE. The natural history of shingles. Roy Coll Gen Pract 1970; 20: 232.

[37]. John S, Merseles JR, Donalkay, Edward Wodoon. Disseminated herpes zoster, a report of 17 cases Arch. India.Med 1964; $1679-86$.

[38]. Bumb R.A, Singhal PK, Jan D, Swroop A. Disseminated herpes zoster with meningoencephalitis. Ind J Dermatol, Venereal, Leprol. 1989;55:256-57.

[39]. Marsilas C, Kaye D, Hook EW.Disseminated Herpes Zoster. Archives of Int. Med. 1964; 113:679. 